\title{
Diagnosis of Bony Metastasis of Renal Cell Carcioma at a Rare Site on Fine Needle Aspiration Cytology: A Rare Case Report
}

\author{
Mohanvir Kaur, Deepika, Vijay Kumar Bodal* and Vikram Jassal \\ Department of pathology, Government Medical College, Patiala, India
}

\section{ABSTRACT}

Fine needle aspiration cytology (FNAC) is cheap, non invasive and time saving procedure in diagnosis and management of patients in developing countries. Metastasis of renal cell carcinoma (RCC) to distant sites and organs at time of presentation is not infrequently encountered in the setting of FNAC for initial diagnosis. Here, we present a case of metastatic RCC to right clavicle initially diagnosed on FNAC and was confirmed on radiological examination of abdomen and histopathological examination.

Keywords: FNAC, Metastasis, Renal Cell Carcinoma, Right Clavicle

\section{Introduction}

Renal cell carcinoma is generally a tumor of adults (average age at diagnosis: 55-60 years). ${ }^{[1]}$ Approximately one-third of patients with renal cell carcinoma already have distant metastasis at the time they seek medical attention.

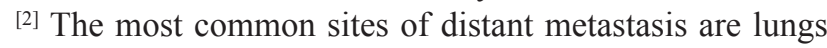
and skeleton. The bones most commonly involved are pelvis and femur, but there is also a predilection for the sternum, scapula and small bones of the hands and feet. ${ }^{[3,4]}$ Metastasis can also develop in the adrenal gland, liver, skin, soft tissue, central nervous system, ovary and almost any other site. ${ }^{[5]}$ Renal cell carcinoma is actually notorious for metastasizing to the most unusual places such as nasal cavity, oral cavity, larynx, parotid, thyroid, heart, bladder, testis, prostate and pituitary gland. ${ }^{[6]}$ These metastasis are often solitary, at least at the clinical level. ${ }^{[7]}$ Because of this and the fact that primary tumor is often clinically silent, these metastasis tend to be confused with primary tumors of the organs in which they lodge.

\section{Case Report}

A 50 year female, presented to the orthopaedics out patient department of our institution with complaint of swelling and pain in right supraclavicular region since 2 months, along with difficulty in over head abduction [Figure-1]. On local examination, a swelling measuring $5 \times 6 \mathrm{~cm}$ in size was present over right clavicle; firm in consistency with local raised temperature. On X-ray examination, an osteolytic lesion was seen involving the lateral half of right clavicle with mild soft tissue bulge query neoplastic, infective, inflammatory [Figure-2]. Routine investigations showed increased $\mathrm{ESR}=65 \mathrm{~mm} / \mathrm{hr}, \mathrm{CRP}=1.0 \mathrm{mg} / \mathrm{dl}$. Ultrasonography of right clavicle was done which revealed a heterogenous mass (? neoplastic) with predominant hypo- echoeic echo pattern measuring $6.0 \times 9.7 \mathrm{~cm}$ in size with increased vascularity on color doppler. Patient was referred to pathology department for FNAC of the clavicular mass.

On examination a pulsatile swelling measuring $5 \times 5 \mathrm{~cm}$ size was present on lateral side of right clavicle. FNAC of the clavicular mass was done and hemorrhagic material was aspirated. Smears were stained with May Grunwald Giemsa (MGG) stain.

On microscopic examination blood mixed smears showed low cell yield with epithelial cells forming clusters, papillaroid structures and papillae with focal fibrovascular core [Figure-3]. The cells were medium sized with foamy vacuolated cytoplasm and single small hyperchromatic nuclei.[Figure-4]. Keeping in view presence of lytic lesion possibility of metastatic deposits of renal cell carcinoma from morphology was kept.

On further investigating the patient, ultrasound and CT scan abdomen was done which revealed right renal mass [Figure-5]. Nephrectomy was done. Specimen was sent to the other institution to confirm the diagnosis of clear cell renal cell carcinoma.[Figure-6], hence confirming the diagnosis of metastatic deposits of renal cell carcinoma on histopathologically.

\section{Discussion}

Renal cell carcinoma is a tumor with an unpredictable clinical course and behavior. Metastases have been reported to develop 17 years or more after the primary lesion is removed. ${ }^{[8]}$

Renal cell carcinoma accounts for approximately $3 \%$ of all the cancer cases. ${ }^{[9]} \mathrm{RCC}$ is the third most common infraclavicular tumor to metastasize to head and neck region 


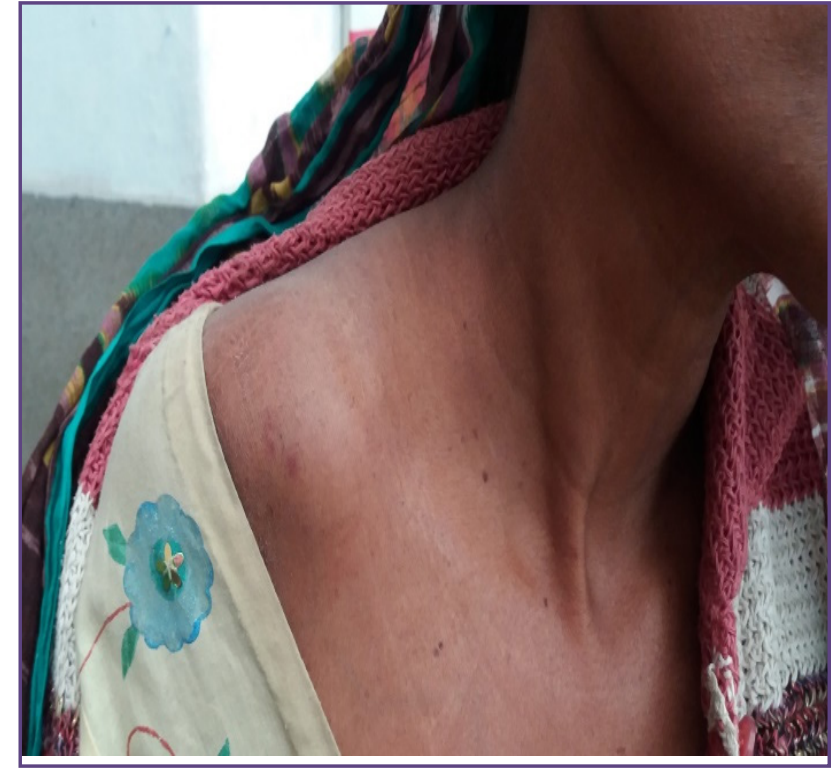

Fig. 1: Photograph of patient showing swelling in right clavicular region.

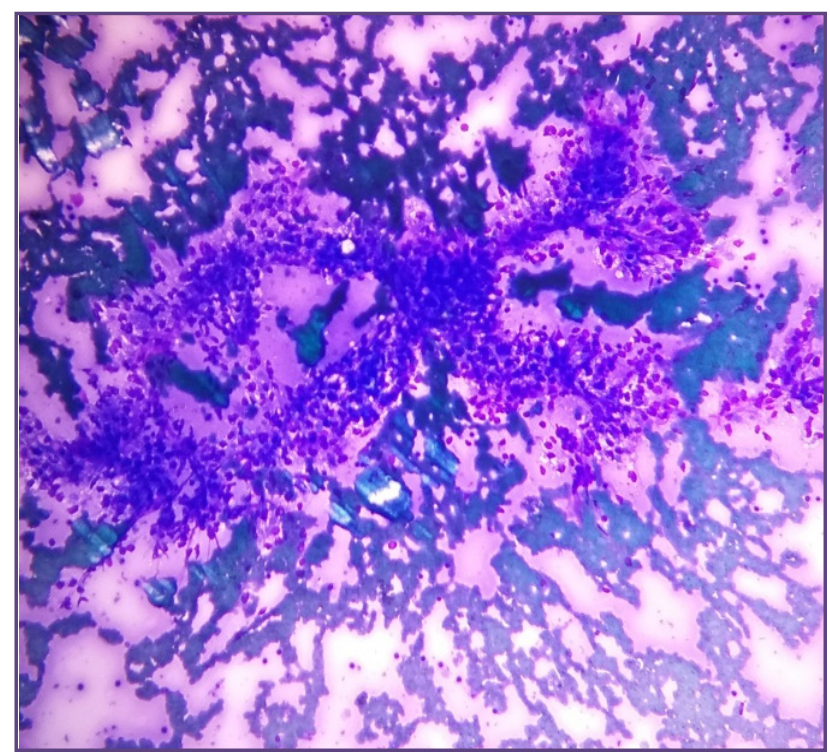

Fig. 3: Blood mixed smears showing epithelial cells forming papillaroid structures and papillae with focal fibrovascular core (MGG, 100x).

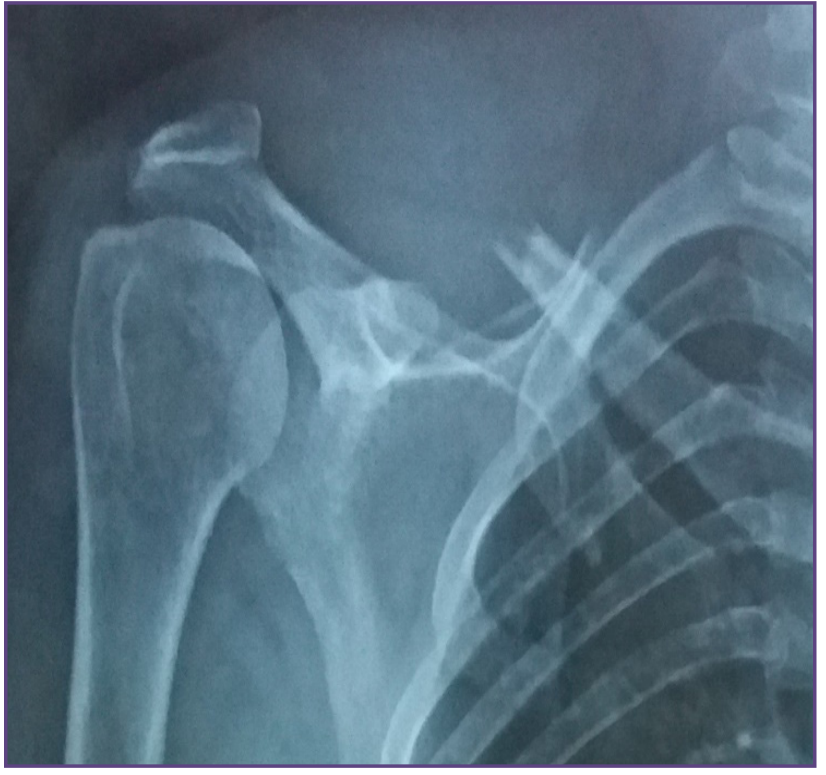

Fig. 2: X-ray right side shoulder joint showing an osteolytic lesion involving the lateral half of right clavicle.

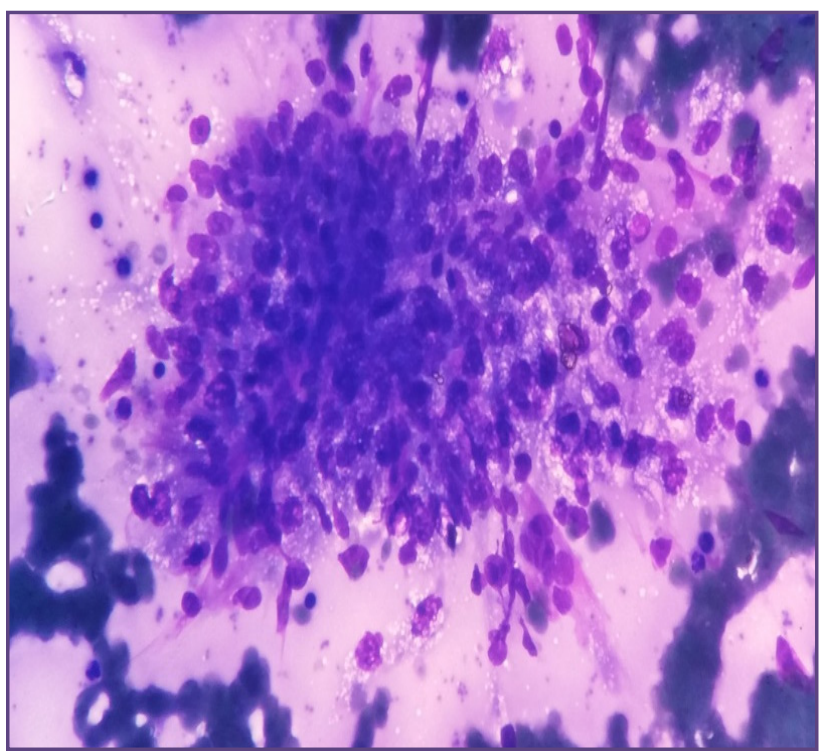

Fig. 4: Blood mixed smears showing medium sized cells with foamy vacuolated cytoplasm and single small hyperchromatic nuclei (MGG, 400 x). 


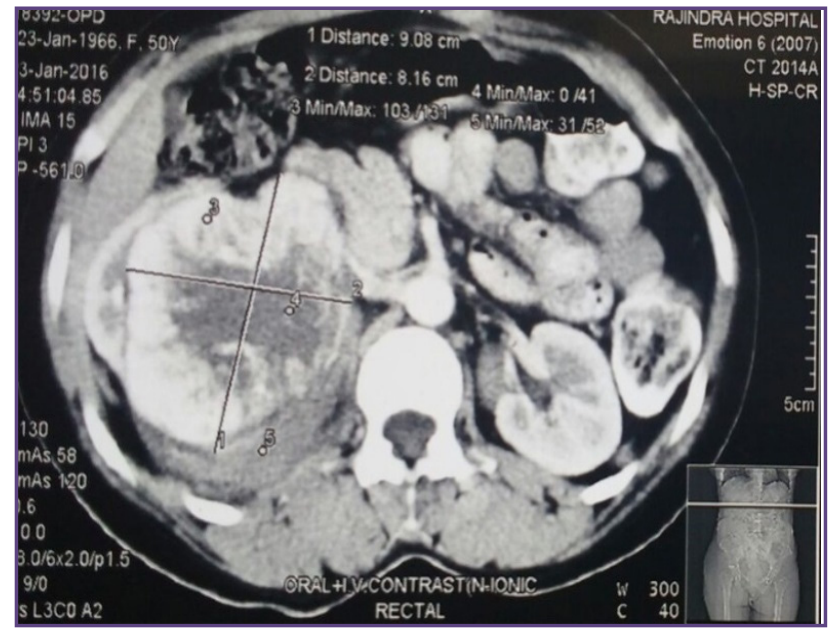

Fig. 5: CECT whole abdomen revealed large lobulated mass arising from upper, middle pole and pelvis of right kidney measuring $9 \mathrm{~cm} \times 8 \mathrm{~cm} \times 7.3 \mathrm{~cm}$.

preceded only by breast and lung. Metastasis solely to head and neck region occurs in only $1 \%$ patients with primary RCC and usually affect thyroid, nose, paranasal sinuses and oral cavity. ${ }^{[10]} 29-57 \%$ of patients develop metastasis by the time tumor is diagnosed. Only $<1 \%$ of patients with bone metastasis manifested clavicular RCC metastasis. Thus clavicular metastasis as the initial presentation of $\mathrm{RCC}$ is extremely rare. Bony metastasis from RCC are purely lytic, expansile and highly vascular. ${ }^{[1]}$

Clavicular symptoms may be manifested before the diagnosis of primary tumours, such as RCC. Clavicular fracture may be the first symptom of tumor metastases to bones. Distinguishing pathological fractures from clavicular fractures due to other causes may help diagnose the primary tumors. $\left[{ }^{12]}\right.$

Characteristically, the tumor is slow-growing and encapsulated in its early stages and thus asymptomatic. When a patient with a clinically asymptomatic renal cell carcinoma has signs and symptoms referable to a localized lesion, the final diagnosis depends on histologic and cytologic evaluation of a biopsy specimen. ${ }^{[13]}$ Microscopically it can be confused with other clear cell carcinomas. Hughes et al. have described prominent vascularity to be an important feature of RCC to distinguish it from other clear cell tumors. ${ }^{[1]}$ Fuhrman nuclear grade used in histology can be applied in cytology smears. ${ }^{[14]}$ Cells of RCC contain intra cytoplasmic fat, hence Oil Red $\mathrm{O}$ staining of air dried smears can be used to distinguish RCC from other clear cell tumors. ${ }^{[15]}$ While metastasis are associated with poor outcome, solitary bone lesions have increased associated survival when compared to multiple bony lesions or a combination of bone and other organs. ${ }^{[16]}$

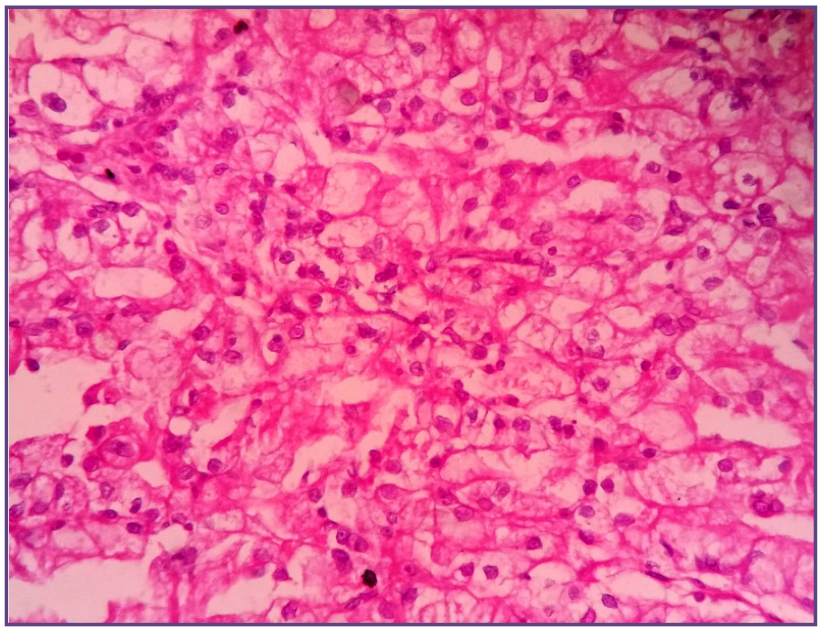

Fig. 6: Smear showing malignant epithelial cells lying in tubules and sheets, exhibiting pleomorphism with sharply outlined cell borders with clear cytoplasm (H \& E,400x)..

Local resection without sacrifice of the vital structures is the treatment of choice depending on the site of presentation. This may provide a chance of cure of the head and neck metastasis and avoid associated morbidity that may occur if the lesion is left untreated. ${ }^{[17]}$

\section{Conclusion}

The case is being presented due to its rare site of metastasis, lytic expansible and highly vascular nature of the lesion which can be misdiagnosed and confused with other clear cell carcinomas. Early diagnosis may increase survival and avoid associated morbidity without sacrifice of vital organs.

\section{Acknowledgements}

We are thankful to Dr. Sarbhjit Kaur, Assistant Professor, Department of Gynaecology, Government medical college, Patiala, for helping us in preparing and writing this article.

\section{Reference}

1. Cohen HT, McGovern FJ. Renal cell carcinoma. N Engl J Med. 2005; 353: 2477-2490.

2. Holland JM. Cancer of the kidney. Natural history and staging. Cancer .1973; 32: 1030-1042.

3. Gurney H, Larcos G, McKay M, Kefford R, Langlands A. Bone metastasis in hypernephroma. Frequency of scapular involvement. Cancer.1989; 64: 1429-1431.

4. Troncoso A, Ro JY, Grignon DJ, Han WS, Wexler H, Von Eschenbach A, Ayala AG. Renal cell carcinoma with acrometastasis. Report of two cases and review of the literature. Mod Pathol .1991; 4: 66-69.

5. Insabato L, De Rosa G, Franco R, D’Onnofrio V, Di Vizio D. Ovarian metastasis from renal cell carcinoma: a report of three cases. Int J Surg Pathol. 2003; 11: 309-312. 
6. Leung CS, Srigley JR, Robertson AR. Metastatic renal cell carcinoma presenting as solitary bleeding prostatic metastasis. J Urol Pathol. 1997; 7: 127-132.

7. Radley MG, McDonald JV, Pilcher WH, Wilbur DC. Late solitary cerebral metastasis from renal cell carcinoma. Report of two cases. Surg Neurol.1993; 39: 230-234.

8. Coppa JF, Oszczakiewicz M. Parotid gland metastasis from renal carcinoma. Int Surg 1990; 75: 198-202.

9. Novick AC, Campbell SC. Renal tumors. Campbell's Urology.2002; 8: 2672-731.

10. Huang HC, Chang KP, Chen TM, Wu KF, Ueng SH. Renal cell carcinoma metastasis in the head and neck. Chang Gung Med J.2006; 29: 59-65.

11. Setlik DE, McCluskey KM, McDavit JA. Best cases from the AFIP: Renal cell carcinoma manifestations - solitary bone metastasis. Radiographics. 2009; 29: 2184-9.

12. Yan K. Jin W. Huan L. Peng G. Jian FX. He-Le F. Pathological clavicular fracture as first presentation of renal cell carcinoma. Cancer Biol. Med 2015; 12: 409-12.
13. Wahner DL, Sebo TL. Renal cell carcinoma:Diagnosis based on metastatic manifestation. Mayo Clin Proc 1997; 72:935-41

14. Hughes JH, Jensen CS, Donnelly AD, Cohen MB, Silverman $\mathrm{JF}$, Geisinger KR et al. the role of fine needle aspiration cytology in the evaluation of metastatic clear cell tumors. Cancer. 1999; 87: 380-9.

15. Wan MW, Husain SN. Fine needle aspiration cytology of metastatic renal cell carcinoma - A case report. Med Health. 2006; 1: 75-80.

16. Parada SA, Franklin JM, Uribe PS, Manoso MW. Renal cell carcinoma metastasis to bone after 33 year remission. Orthopaedics. 2009; 32: 446.

17. Yeh HC, Yang SF, Ke HL, Lee KS, Huang CH, Wu WJ. Renal cell carcinoma presenting with skull metastatsis: a case report and literature review. Kaoh J Med Sci 2007; $23: 475-78$.

*Corresponding author:

Dr Vijay Kumar Bodal, Department of pathology, Government Medical College, Patiala, India

Phone: +91 9814714946

Email: vijay_bodal@gmail.com

Date of Submission : 22.10.2016

Date of Acceptance : 10.03.2017

Financial or other Competing Interests: None.
Date of Publication : 29.05.2017 